\title{
PENYULUHAN KEWIRAUSAHAANA BAGI KARANG TARUNA DI DESA PAPAHAN, KECAMATAN TASIKMADU, KABUPATEN KARANGANYAR
}

\author{
Suprayitno $^{1)}$ dan Erni Widajanti ${ }^{2)}$ \\ ${ }^{1,2)}$ Fakultas Ekonomi Universitas Slamet Riyadi Surakarta \\ e-mail: ${ }^{1)}$ suprayitno29@yahoo.co.id \\ erni-widajanti@yahoo.co.id
}

\begin{abstract}
This extension activity was conducted for Karang Taruna Desa Papahan, Kec. Tasikmadu, Kab. Karanganyar. The outcomes of this activity are: cheap participants' knowledge of the concept of entrepreneurship so that they have the right knowledge; benefit participants' insights on how to start a business and choose the right type of business; benefit participants' insights about possible business failures and ways to enter and resolve business failures.

This activity is carried out with the following stages: Selection of participants to the community service, namely the board and members of Karang Taruna; Submission of lecture materials, with a view to fostering an entrepreneurial spirit; Implementation of evaluation Evaluation is done by: before counseling conducted a question-answer to know each participant's initial knowledge about entrepreneurship special techniques or how to start a business. After the counseling finished the question and answer again about the same material. By comparing the results of answers that have been done, it will be known whether there is an increase in knowledge about the entrepreneurship and scope.
\end{abstract}

Keywords: Counseling, entrepreneurship, management

\section{Pendahuluan}

Seperti diketahui bahwa dalam menumbuhkan jiwa wirausaha di kalangan generasi muda seringkali menghadapi kendala, baik kendala internal maupun kendala eksternal. Kendala internal terutama berkaiatan dengan sumber daya manusia. Sedangkan kendala eksternal berkaitan dengan iklim usaha yang kurang kondusif terhadap perkembangan sektor usaha kecil, regulasi-regulasi pemerintah yang kurang mendukung dunia wirausaha dan kendala-kendala lainnya. Selama ini terkesan berbagai kebijaksanaan lebih berpihak kepada sektor usaha besar, sehingga berbagai fasilitas yang disediakan oleh pemerintah sebagian besar dinikmati oleh sektor usaha besar. Kondisi seperti ini sudah seharusnya 
mendapatkan perhatian berbagai pihak untuk dapat mencari jalan keluar untuk mengatasinya.

Dengan berbagai kendala yang ada pada sektor usaha kecil pemerintah dan pihak swasta telah melaksanakan berbagai alternatif pendekatan untuk menumbuh-kembangkan mereka. Untuk pengembangan yang selama ini dilakukan antara lain :

\section{Pola keterkaitan dan kemitraan}

Pola ini pada dasarnya berusaha mengkaitkan sektor usaha kecil dan sektor usaha besar. Sektor usaha kecil diharapkan bisa menjadi pemasok (sektor hulu) maupun menjadi sektor hilir dari kegiatan sektor usaha besar. Dalam perkembangannya pola ini berkembang menjadi pola bapak angkat dan anak angkat. Simbiosis mutualisme antar dua pihak bisa saling terkait dan masingmasing pihak dapat merasakan manfaatnya.

2. Menciptakan iklim usaha yang kondusif untuk tumbuh dan berkembangnya sektor usaha kecil.

Kondisi tersebut dapat diciptakan dengan memberikan kesempatan yang lebih besar kepada sektor usaha kecil untuk akses terhadap pasar, akses terhadap sumber pembiayaan, dan akses terhadap teknologi. Peningkatan akses pasar dapat dilakukan dengan memberikan “proteksi”. Bidang-bidang usaha kecil tertutup bagi sektor usaha besar. Peningkatan akses terhadap sumber pembiayaan dapat dilakukan dengan memberi kemudahan dalam mengakses kredit perbankan. Akses terhadap teknologi dapat dilakukan melalui diklat. Dalam diklat tersebut sektor usaha kecil diharapkan memperoleh berbagai informasi baru mengenai teknik produksi. Di sini diperlukan iklim yang mendukung terjadinya alih teknologi dari sektor usaha besar (baik pemerintah atau swasta) terhadap sektor usaha kecil.

3. Peningkatan kualitas sumber daya manusia.

Usaha tersebut dapat dilakukan melalui pendidikan dan pelatihan (diklat) untuk meningkatkan kemampuan manajerial, kemampuan praktik, maupun kewirausahaan. Bagi pengusaha kecil akan lebih mudah belajar secara praktik dibanding belajar secara teori yang rumit. Jadi berbagai bentuk magang, 
inkubator bisnis, klinik usaha dan konsultasi usaha merupakan pendekatan yang tepat untuk mereka.

Generasi muda sekarang ini umumnya masih banyak yang berharap ingin mendapatkan pekerjaan di kantor-kantor milik pemerintah dan swasta. Sangat sedikit yang ingin mandiri dengan cara berwirausaha. Oleh karena ini kami ingin membantu program pemerintah dalam menumbuh-kembangkan minat berwirausaha di kalangan generasi muda. Pada program pengabdian masyarakat saat ini, kami lakukan terhadap seluruh anggota Karang Taruna Desa Papahan, Kecamatan Tasikmadu, Kabupaten Karanganyar

\section{Target}

Kegiatan ini dilakukan dalam bentuk Penyuluhan dan diharapkan dapat memberikan wawasan bagi seluruh peserta yang berasal dari para anggota Karang Taruna Desa Papahan, Kecamatan Tasikmadu, Kabupaten Karanganyar, untuk memiliki pengetahuan, ketrampilan, sikap mental dan keberanian memulai wirausaha sehingga mereka dapat memiliki usaha dan dapat mengelola usahanya dengan baik dan tidak hanya selalu menggantungkan diri menjadi pegawai baik keinginan menjadi pegawai swasta maupun pegawai negeri (PNS) saja. Melalui kegiatan ini diharapkan mereka dapat:

1. Memahami konsep kewirausahaan secara utuh, sehingga peserta dapat memiliki minat untuk masuk dunia wirausaha dan agar mereka memiliki pengetahuan yang benar.

2. Memberikan wawasan tentang bagaimana memulai suatu usaha dan memilih jenis usaha dengan benar, sesuai dengan talenta dan bakat yang mereka miliki sehingga diharapkan peserta termotivasi dan dapat segera mempunyai keinginan untuk membuka usaha.

3. Memberikan wawasan tentang kemungkinan kegagalan usaha dan cara-cara untuk mengantisipasi dan mengatasi kegagalan usaha. 


\section{Luaran}

Luaran dari kegiatan ini adalah:

1. Meningkatnya pengetahuan peserta mengenai konsep kewirausahaan agar mereka memiliki pengetahuan yang benar tentang dunia wirausaha, sehingga dapat menumbuhkan minat bagi para peserta untuk memulai berwirausaha.

2. Meningkatnya wawasan peserta tentang bagaimana memulai suatu usaha dan memilih jenis usaha dengan benar, sesuai dengan bakat dan talenta mereka. Karena disadari masing-masing individu memiliki talenta dan bakat yang berbeda-beda satu dengan yang lainnya.

3. Meningkatnya wawasan peserta tentang kemungkinan kegagalan usaha dan cara-cara untuk mengantisipasi dan mengatasi kegagalan usaha. Dengan demikian jika mereka sudah masuk ke dalam dunia wirausaha memiliki mental yang bagus, tidak gampang menyerah dan berputus asa, jika menghadapi kemungkinan-kemungkinan resiko yang akan dihadapi.

\section{Metode Kegiatan}

Kegiatan ini dilakukan dengan tahapan-tahapan sebagai berikut:

1. Penyuluhan, dengan maksud untuk memberikan wawasan dan pengetahuan tentang dunia wirausaha, sehingga dengan memiliki wawasan dan pengetahuan yang baik diharapkan akan dapat menumbuhkan jiwa wirausaha.

2. Pendampingan, dengan maksud untuk mengatasi kesulitan-kesulitan yang dihadapi. Dalam proses memulai usaha sangat disadari peserta akan banyak menghadapi hal-hal baru yang mungkin sulit untuk mereka pecahkan, sehingga sangat disadari juga mereka membutuhkan pendampingan dalam proses pelaksanaannya.

3. Pemantauan hasil penyuluhan oleh tim pengabdian ini untuk mengetahui sejauh mana kemampuan dari para generasi muda dalam mengatasi hambatan yang dihadapi (modal, kemampuan sumber daya manusia, kemampuan mengelola usaha), setelah menerapkan hasil penyuluhan yang telah diperoleh.

4. Evaluasi terhadap peserta dilakukan dengan cara tanya-jawab dan melalui beberapa test bakat dan minat untuk mengetahui jenis usaha apa yang cocok bagi masing-masing para peserta. Dalam evaluasi juga dilakukan dengan cara 
para peserta menjawab pertanyaan-pertanyaan yang untuk menguji pemahaman peserta tentang materi yang sudah diterima.

\section{Metode Evaluasi}

Sebelum penyuluhan dilakukan pre-test untuk mengetahui pengetahuan para peserta tentang dunia kewirausahaan, setelah penyuluhan selesai, dilakukan test lagi dengan soal yang sama. Dengan membandingkan hasil jawaban yang telah dilakukan, maka akan diketahui apakah ada peningkatan ataukah tidak, dalam hal pengetahuan mengenai teknik memulai usaha dan manajemen pengelolaan usaha. Disamping bentuk test seperti tersebut di atas, dilakukan evaluasi juga dalam bentuk diskusi dan tanya-jawab, berkaitan dengan pemahaman peserta tentang materi yang telah disampaikan, dengan demikian dapat diketahui daya tangkap peserta dan dapat segera ditindaklanjuti untuk meluruskan jika masih ada pemahaman-pemahanan yang belum benar.

\section{Hasil dan Pembahasan}

Pelaksanaan kegiatan ini merupakan salah satu upaya mewujudkan Visi dan Misi Universitas Slamet Riyadi Surakarta, yaitu menjadi lembaga pendidikan tinggi berkualitas yang dapat berperan aktif dalam pengembangan IPTEKS untuk kesejahteraan umat manusia yang berkelanjutan, menjunjung tinggi budaya bangsa dan berjiwa Pancasila. Dimana dalam misi Universitas disebutkan Unisri menyelenggarakan kegiatan penelitian dan pengabdian, menerapkan serta menyebarluaskan IPTEKS untuk meningkatkan kesejahteraan umat manusia dan menyelenggarakan pembelajaran yang mengembangkan semangat kewirausahaan.

Selain mewujudkan visi dan misi Unisri Surakarta, kegiatan pengabdian masyarakat ini juga menunjang visi dan misi Fakultas Ekonomi Unisri, terutama misi yang ketiga, Dimana Misi yang ketiga Fakultas Ekonomi adalah mengembangkan dan menyebarluaskan Ilmu pengetahuan khususnya di bidang Manajemen dan akuntansi untuk meningkatkan taraf hidup masyarakat. 
Hasil yang dicapai dari program pengabdian kepada masyarakat ini meliputi :

1. Peserta memahami dan dan memiliki pengetahuan bagaimana cara memulai sebuah usaha atau bisnis. Apakah harus dimulai dari modal uang, kemauan yang kuat atau relasi.

2. Menghasilkan generasi muda yang memiliki minat untuk menjadi seorang wirausaha, bisa sebagai produsen dalam bentuk barang maupun dalam bentuk jasa.

3. Bila generasi muda ada motivasi yang kuat untuk menjadi seorang wirausahawan, maka akan memajukan dan mengembangkan daerah yang bersangkutan, imbasnya ekonomi daerah akan meningkat dan ekonomi secara menyeluruh (makro) akan semakin baik.

4. Meningkatnya motivasi Karang Taruna di kampung Gebang untuk berwirausaha dan bisa melakukan pengelolaan keuangan secara benar, sehingga mereka akan bisa menyusun strategi dan akhirnya bisa menjadi unggul dalam memilih usahanya. Meningkatnya pengetahuan para generasi muda dalam hal tehnik memulai usaha dan pengelolaan keuangan dengan baik.

5. Meningkatnya pengetahuan di dalam mencari akses pasar, khususnya keberhasilan dalam menciptakan repeat order (captive market) dan market driver (open market).

6. Meningkatnya kemampuan para generasi muda dalam hal mengelola usaha.

Untuk menindaklanjuti kegiatan pengabdian kepada masyarakat ini, maka rencana kegiatan kedepan yang perlu dilakukan adalah mengadakan kegiatan lanjutan dengan materi yang berbeda untuk menjadikan pengetahuan peserta menjadi lebih komprehensif. Kami berharap kegiatan kedepan lebih banyak pedampingan kepada para Karang taruna yang tegabung dalam kelompok usaha bersama di Desa Papahan, Kecamatan Tasikmadu, Kabupaten Karanganyar. Hal ini kami lakukan agar usaha yang telah dilakukan dapat kami awasi perkembangannya. Seandainya ada masalah yang dihadapi, secepatnya dapat dicari solusinya. 


\section{Kesimpulan dan Saran}

\section{a. Kesimpulan}

Kegiatan Penyuluhan ini dilaksanakan Di Desa Papahan, Kecamatan Tasikmadu, Kabupaten Karanganyar. Peserta kegiatan ini adalah anggota dan pengurus Karang Taruna.

Manfaat yang dapat dirasakan dari kegiatan ini:

1. Meningkatnya pengetahuan para generasi muda dalam hal tehnik memulai usaha dan pengelolaan keuangan dengan baik.

2. Meningkatnya pengetahuan di dalam mencari akses pasar, khususnya keberhasilan dalam menciptakan repeat order (captive market) dan market driver (open market).

3. Meningkatnya kemampuan para generasi muda dalam hal mengelola usaha.

\section{b. Saran}

Anggota Karang Taruna dan Pendamping Karang Taruna memberikan respon positip atas kegiatan Penyuluhan ini dan diharapkan penyuluhan lanjutan sangat diharapkan.

Kegiatan ini akan lebih efektif bila melibatkan atau ada kerjasama antara Dinas Perindustrian, Perdagangan dan Koperasi Kota Surakarta (sebagai instansi pemerintah), perbankan (sebagai lembaga penyedia dana), dan Fakultas Ekonomi UNISRI Surakarta (sebagai penyuluh dan pelatih di bidang peningkatan kualitas SDM dan manajemen usaha). 


\section{Daftar Pustaka}

Harimurti Subanar, 2001, Manajemen Usaha Kecil, BPFE, Yogyakarta.

Longenecker, Justin G., et al., 2001, Kewirausahaan : Manajemen Usaha Kecil, Salemba Empat, Jakarta.

R. Maryatmo dan Y. Sri Susilo, 1996, Dari Masalah Usaha Kecil sampai Masalah Ekonomi Makro, Univ Atmajaya, Yogyakarta.

Suparman Sumahamijaya, 2014, Membina Sikap Mental Wiraswasta, Gunung Jati. Jakarta.

Wasty Soemanto, 1992, Pendidikan Wiraswasta, Bumi Aksara, Jakarta. 